IZA DP No. 1399

Marital Fertility and Religion:

Recent Changes in Spain

Alicia Adsera

November 2004 


\title{
Marital Fertility and Religion: Recent Changes in Spain
}

\author{
Alicia Adsera \\ University of Illinois at Chicago, \\ University of Chicago and IZA Bonn
}

Discussion Paper No. 1399

November 2004

\author{
IZA \\ P.O. Box 7240 \\ 53072 Bonn \\ Germany \\ Phone: $+49-228-3894-0$ \\ Fax: +49-228-3894-180 \\ Email: iza@iza.org
}

\begin{abstract}
Any opinions expressed here are those of the author(s) and not those of the institute. Research disseminated by IZA may include views on policy, but the institute itself takes no institutional policy positions.

The Institute for the Study of Labor (IZA) in Bonn is a local and virtual international research center and a place of communication between science, politics and business. IZA is an independent nonprofit company supported by Deutsche Post World Net. The center is associated with the University of Bonn and offers a stimulating research environment through its research networks, research support, and visitors and doctoral programs. IZA engages in (i) original and internationally competitive research in all fields of labor economics, (ii) development of policy concepts, and (iii) dissemination of research results and concepts to the interested public.
\end{abstract}

IZA Discussion Papers often represent preliminary work and are circulated to encourage discussion. Citation of such a paper should account for its provisional character. A revised version may be available directly from the author. 
IZA Discussion Paper No. 1399

November 2004

\title{
ABSTRACT
}

\section{Marital Fertility and Religion: Recent Changes in Spain*}

Since the onset of democracy in 1975, both total fertility and Mass attendance rates in Spain have dropped dramatically. I use the 1985 and 1999 Spanish Fertility Surveys to study whether the significance of religion in fertility behavior - both in family size and in the spacing of births - has changed. While in the 1985 SFS family size was similar among practicing and non-practicing Catholics, practicing Catholics portray significantly higher fertility during recent years. In the context of lower church participation, religiosity has acquired a more relevant meaning for demographic behavior. Among the youngest generation, non-practicing Catholics behave as those without affiliation. The small group of Protestants and Muslims has the highest fertility and interfaith unions are less fertile.

JEL Classification: $\quad \mathrm{J} 1, \mathrm{Z} 12$

Keywords: fertility, religion, religiosity, Spain, timing of births

\author{
Alicia Adsera \\ Department of Economics \\ University of Illinois at Chicago \\ 601 S. Morgan St. \\ Chicago IL 60607 \\ USA \\ Email: adsera@uic.edu
}

\footnotetext{
* Financial help from NICHD is gratefully acknowledged. I would like to thank Carles Boix, and Evelyn Lehrer for their comments and Kevin Bowman for excellent research assistance.
} 


\section{INTRODUCTION}

Total fertility rates in Europe have recently plummeted to previously unknown low levels. Within Europe, Spain has suffered the sharpest changes. Total fertility rates have decreased from 2.8 in 1975 to 1.15 in 1997 and only slightly revamped to 1.2 in recent years. Since the mid 1970 s Spain has also undergone important economic, social and political transformations. Among those, a country traditionally considered a Catholic bastion has now very low church attendance rate, particularly among its youth. In this paper I use information on religious affiliation and religiosity from the 1985 and 1999 Spanish Fertility Surveys (SFS) to study the relevance of that change on religious behavior in Spanish fertility. I focus on the effect religiosity and the religious make up of couples have on both family size and the timing of births.

Undoubtedly several competing forces are responsible for recent Spanish demographic transformations. First, the decrease of fertility rates coincides in Spain with a period of high and persistent unemployment. The increase in employment uncertainty since the mid 1980s played a key role in the overall decline in family sizes and delayed childbearing in all Western Europe (Adsera 2004 a, b). In Spain, mature workers held protected jobs while the young cohorts experienced high turnover rates across precarious jobs in the lower end of a dual market. Young women faced a choice of sticking to their unstable job trading off childbearing for the hope of employment security or struggling to re-enter the labor force after childbirth (Adam 1996). The lack of employment stability among young men reinforced the depressing effect on fertility of this institutional framework (Ahn and Mira 2001, Gutierrez-Domenech 2002, Adsera 2004 b). Second, fewer places in Europe witnessed more dramatic changes in women's education than Spain during the last 30 years. Whereas 74\% of women born between 1935 and 1949 had an education level lower than 8th grade and only $1.9 \%$ had a four-year college degree, those percentages stood at 
$17.5 \%$ and $12.3 \%$ respectively for those born in 1964-68. Both due to the adverse economic environment and to the increasing educational investment of Spanish women, childbearing was progressively postponed. The percentage of women childless at age 30 moved up from $9.6 \%$ among those born $1949-53$ to $24.7 \%$ for the $1964-68$ cohorts.

Aside from economic and educational factors that have played major roles in the fall of family size, the fast secularization of the country deserves close attention. Previous research has extensively highlighted the relevance of religious affiliation and religiosity in a wide range of economic and demographic outcomes such as marital stability (Lehrer and Chiswick 1993), union formation (Thornton et al. 1992, Sander 1993, Lehrer 2004), educational attainment (Chiswick 1988, Lehrer 1999) and, at the macro level, economic growth (Barro and McCleary 2003). With regard to fertility, much of the focus has been on exploring interdenominational differences in family size in the US population. Among denominations, previous analyses of the behavior of Catholics are the most relevant for this paper since the majority of Spaniards consider themselves Catholics. In the late 1970s, after years of consensus that Catholics had significantly larger families than non-Catholics living in the US, Westoff and Jones (1979) pointed out that fertility rates of those groups were rapidly converging due to the sharp decrease in Catholic fertility, a result confirmed in subsequent research (Lehrer 1996). O'Grada (1995) found a similar convergence in Northern Ireland. Attention has gradually shifted to analyze the impact of religious attendance on birth rates. Several papers have shown an increased polarization within US Catholics, with significantly higher fertility among those with more frequent church attendance (Mosher and Hendershot 1984, Williams and Zimmer 1990, Sander 1992).

In this paper I compare the effect of religious affiliation on the fertility behavior of those interviewed in 1985 versus 1999 to see whether both the decreased relevance of Catholic affiliation 
but the increased importance of religiosity are also present in recent Spanish demographic changes. Further I analyze whether the religious makeup of Spanish couples matters for fertility behavior as it has been found in US data (Lehrer 1996).

Next the main hypotheses of the paper are presented. A description of the data and methodology follows. The next two sections discuss the estimated differences on the predicted family size and on the timing of the first three births among different religious groups in Spain. A summary of the main results closes the paper.

\section{THE ANALYTICAL FRAMEWORK}

\section{The Relevance of Religious Affiliation}

During the last three decades, developed countries have undergone an ensemble of changes such as delays in age at first birth and in marriage as well as increases in extra-marital births and in cohabitation-in the context of the "second demographic transition" (Van de Kaa 1987). Profound changes in values have been found to be at the center of these demographic transformations (Lesthaeghe and Surkyn 1988, Bumpass 1990). Changes have been faster in those countries where they started later, such as in Spain and the rest of Southern Europe, possibly due a quicker entrance of women in the labor market and to information flowing from their neighbors (Becker and Murphy 2000). Surkyn and Lesthaeghe (2004) note that, while already widespread in most Western Europe, Portugal and Spain increasingly exhibited the characteristics of the Second Demographic Transition since the middle of the 1980. They attribute those changes to an accentuation of individual autonomy and a fast process of secularization, defined as a reduction in religious practice, abandonment of traditional religious beliefs and a decline in individual sentiments of religiosity. 
Spain has traditionally been a Catholic country. During the Franco regime from 1939 until 1975, the political regime made a point of preserving Spain as a bastion of Catholicism. In the context of the economic analysis of religion it is widely expected that where religions are statesupported, religious practice is low (Iannaccone and Stark 1994). Interestingly enough, even if Catholicism could have been viewed as a State Church, religious participation in Spain during that period was relatively high and socially respected. Among other reasons, church attendance might have proven in many surroundings an asset to building networks or social capital (Sacerdote and Glaeser 2001). However, the intimate link of State and Catholicism collapsed at the onset of democracy in 1975 and, with it, church attendance rates. Spain was still a country with only one major religion but the lack of social gains from Mass attendance induced a better sorting between both groups practicing and non-practicing Catholics. In that environment, the rapid secularization of Spanish society was not unexpected (Iannaccone and Stark 1994). Religious practice acquired a more accurate meaning. Branas and Neuman (2004) show how, even though the majority of Spaniards still define themselves as Catholics, only a minority attends Mass regularly, prays and strongly believes in some teachings of the church such as afterlife, heaven, hell or miracles. Religiosity has remained relatively higher among women.

Previous literature analyzing interdenominational differences of fertility has noted the more pronatalist orientation of certain churches such as Conservative Protestants, Catholics, and especially Mormons (Lehrer 1996). Among Catholics, a possible source of those differences may lie on Church teachings, which impose a restrictive use of contraception. However, it is widely acknowledged that adherence to those recommendations among Catholics has weakened 
substantially. ${ }^{1}$ The most recent data on the use of modern methods of contraception put Spain, where $67.5 \%$ of all married women of reproductive age use them (and $81 \%$ use some contraceptive method), at a level similar to that of Northern European countries or United States, and well above other traditionally Catholic countries such as Italy or Austria (with a 39\% and 46.8\% prevalence, respectively, of moderns contraceptive use) (United Nations 2002). Interestingly, the 1985 and 1999 Spanish Fertility Surveys do not only show that the youngest cohorts quickly adopted contraceptive methods, but that differences in their use between practicing and non-practicing Catholics were small. Among married women in the 1985 survey, 58\% of practicing Catholics, $69 \%$ of non-practicing Catholics and $73 \%$ of those without religion have used contraceptives. Among women born after 1950 , those shares stand at $70 \%, 76.8 \%$ and $79 \%$ respectively. In the 1999 Survey, the percentage of married women having ever used a modern method of family planning is fully $82 \%$ of practicing Catholics, $91 \%$ of non-practicing Catholics and $92.3 \%$ of the unaffiliated. Wide availability and use of contraceptives place more control over family planning on Spanish women than in previous generations.

In addition to the use of family planning, an important avenue through which pronatalist differences among religious affiliations can influence family size is through variation in the desired family size. A recent study for 13 OECD countries finds a significant difference in the ideal number of children between young practicing and non-practicing Catholic women. Whereas the mean ideal number of children among non-practicing Catholic women under 30 years of age surveyed in the ISSP study on Family and Gender Roles in 1994 was 2.57, not significantly

\footnotetext{
${ }^{1}$ To some this would account for the fast decline in family size among Catholics (Goldscheider and
} Mosher 1991, Mosher et al. 1986). 
different from the 2.53 of those without religious affiliation, the mean of 2.86 for practicing Catholics was significantly higher (Adsera 2003).

From the arguments just laid out the main hypotheses of the paper follow. First, Catholic affiliation per-se seems to have lost some of its distinctive traits given the lower church attendance and wide use of family planning among Spaniards. As a result, fertility behavior of individuals declaring Catholic affiliation is not necessarily different from other groups. Second, as a better sorting process has occurred among Catholics with dwindling overall attendance and the disappearance of potential networking gains present under the previous political regime, I expect to observe an increasingly larger differential behavior over the years between practicing and non practicing Catholics. Individuals with high religiosity are expected to follow more closely the church teachings and, given recent results for the OECD data shown above, to seek larger families.

Even though most Spaniards consider themselves, at least nominally, Catholics, the minority of Muslims and Protestants (mainly from conservative denominations) is steadily growing. Individuals identifying themselves as belonging to small denomination groups in a not too pluralistic country are more likely to be committed to their affiliation. Both Muslims and Conservative Protestants can be easily labeled as pronatalist groups. Among Conservative Protestants this is supported by their differentially lower contraceptive use and their relatively higher fertility and desired number of children (Goldscheider and Mosher 1991, Lehrer 1996, Adsera 2003). Morgan et al. (2002) provide an analysis of the reasons for the differentially higher fertility of Muslims as well as a good overview of the literature on the subject. As a result, a third hypothesis of the paper is an expected higher family size of smaller pronatalist churches in a not yet too pluralistic society. 


\section{Religious Composition of the Couple}

Becker et al. (1977) suggest that the religious composition of unions, whether inter-faith (heterogamous unions) or homogamous unions, should influence their fertility, because children represent "spouse-specific" human capital, capital that decreases in value following marriage dissolution. The lower stability on inter-faith marriages should thus reduce the number of births within those marriages. Chiswick and Lehrer (1993) find strong evidence of a larger fragility of intermarriages. Using U.S. data Lehrer (1996) finds support for the hypothesis that inter-faith couples restrict their fertility, even while the marriage is in place. This result is interpreted as indicating that such couples are aware of the increased frailty of their union, and hence invest less in spouse-specific capital. The particular religious make up of the marriage also matters because the larger the difference in religious background, the more likely conflict will arise in the desired number of children. Lehrer (1996) finds a significant negative effect of out-marriage on fertility for Mormon and Catholic women, two pro-natalist groups.

Since the 1999 SFS includes the husband's religious affiliation, it can be used to test whether the religious composition of couple affects fertility behavior in the case of Spain. A final hypothesis follows naturally from the discussion above. I expect to find lower family sizes in interfaith marriages due to both lower couple specific investments and to bargaining conflict. In the analysis, I consider that a practicing Catholic married to a non-practicing Catholic form a heterogamous union. The specific composition of those couples is likely to matter. Given that the majority of Spaniards still acknowledge a Catholic upbringing, larger differences in background, from a non-Catholic spouse, are expected to result in more frequent marriage conflict and, potentially, lower fertility in those unions. 


\section{METHODOLOGY}

\section{Data}

I use the 1985 and 1999 SFS which were addressed to women aged 15 to 49, living in Spain. The surveys follow the guidelines of the Fertility Surveys from the United Nations. Their main purpose is to obtain information about the demographic characteristics of women of childbearing age, their social and family environment as well as the factors that determine the level of fertility. One woman was interviewed in each household. The total number of interviews available in the 1985 Survey was 8,782 and we have complete information on 5,437 married women. In the 1999 Survey, a total of 7,749 respondents were interviewed and the sample includes complete information on 4,346 marriages. To study the spacing of births we have complete information for 4,466 first births, 3,264 second births and 1,521 third births from the 1985 Survey. Data in the 1999 survey include complete information on 3,804 first births, 2,745 second births and 756 third births.

The 1999 survey provides information on the religious affiliation of the woman and her spouse. Only that of the woman is included in the 1985 Survey. The question is posed about current religious beliefs and no information is available on the religious family background. As noted, the majority of Spaniards have a Catholic upbringing and the main distinction between individuals is whether they consider themselves practicing or not. In the 1985 Survey the possible answers are grouped in four categories: practicing Catholic, non-practicing Catholic, no religion and other religion (a small mixed group that contains mainly Muslims and Conservative Protestants). Table 1 presents the means of the religion variable for the whole sample of married women and for those born in 1950 and after. The majority of women (61.2\%) consider themselves practicing Catholics in the whole sample. Among those born in 1950 and after, the proportion of practicing and nonpracticing is similar, $49 \%$ and $47 \%$ respectively. 
Table 2 includes the means of religious variables for the 1999 Survey, both for the complete sample as well as for those born in 1960 or after. The 1999 Survey provides five distinct categories: practicing Catholic, non-practicing Catholic, no beliefs, other religion (mainly Muslims and Conservative Protestants) and own beliefs. The proportion in this last category is not negligible and the analysis shows that their behavior is slightly different to that of individuals without beliefs. In general, this answer is expected to come from non-conformist individuals (Surkyn and Lesthaeghe 2004). The majority of women in the 1999 Survey are non-practicing Catholics (48.8\%) and the proportion increases for the young generation (54.3\%). Both the shares of other religion and of those without affiliation -those with own beliefs and no beliefs- are, now, larger than in the 1985 survey. Around $15 \%$ of the couples are formed of spouses with different religious background, and, in two thirds of those marriages, the husband is Catholic. A set of interaction variables indicates the proportion of marriages for each religious affiliation of the woman for which the husband has a different affiliation. The largest proportion of heterogamous marriages has a Catholic practicing woman, around $9 \%$ of the sample. Finally, an additional set of variables displays a range of different religious composition for couples in the sample. For that group of variables the category no affiliation includes both no beliefs and own beliefs. Table 2 shows that, among couples with women born in 1960 or after, half of them are homogamous couples of non-practicing Catholics this is up from $45 \%$ for the whole sample. Slightly over a quarter of them are homogamous couples of practicing Catholics -this is down from around a third of the complete 1999 sample.

The analyses in this paper are restricted to marital fertility. Until very recently Spaniards moved out of their parents' homes at the time of marriage. Consensual unions were rare. In the 1999 Survey, such unions are still relatively uncommon, though their prevalence is substantially higher among the youngest generation has increased rapidly. First births within a consensual union 
constitute $2.5 \%$ of total first births reported in the 1999 SFS and $3.9 \%$ of those among women born in 1960 or after. Given the difficulty of establishing a proper comparative date of start of the relationship I choose to present results of births within a marriage. The conclusions of the paper are robust to estimations with an alternative sample that includes cohabitants; these are available from the author.

Table 3 includes the means of the control variables included in the estimates. Benchmark values are reported in brackets. For the 1985 estimates I control whether either the wife or the husband had more than 2 siblings. This information is not available for the 1999 survey. Duration of the marriage, wife's and husband's education at the time of the survey, region of residence as well as size of the city of residence are included in the analyses of both samples. City sizes for the 1985 Survey are: rural, small (under 100,000 inhabitants) and large (over 100,000). For the 1999 Survey: rural (less 10,000), small (10,000-50,000), medium $(50,000-500,000)$ and large (over 500,000). Educational groups include those with no studies, primary, low secondary (the omitted category), completed high school, vocational school and two-year and four-year college degrees. ${ }^{2}$ In estimates with the 1999 Survey, no studies and primary education were pooled together. Coefficients of the control variables are not reported in the Tables since the focus of the paper is on the role of religion. However, at the end of each section I report the results for these controls and estimates can be obtained from the author.

\footnotetext{
${ }^{2}$ In Spain vocational schools are offered as a parallel track to high school and community colleges.
} 


\section{Empirical Specification}

The first part of the paper analyzes differences in family size by the woman's religious background and by the religious composition of the union using ordinary least squares. The dependent variable is the number of children born within the marriage. ${ }^{3}$

In the second part of the paper I study the differences of timing to the first three births across women and couples of different religious background. I use individual level data to estimate Cox proportional hazard models of the timing of births across the European Union. For women $\mathrm{i}=$ $1, \ldots, \mathrm{N}$, who each enter a state (e.g. first birth) at time $\mathrm{t}=0$, the (instantaneous) hazard rate function for ith person at time $\mathrm{t}>0$ is assumed to take the proportional hazards form

$$
\lambda_{\text {it }}=\lambda_{0}(\mathrm{t}) \mathrm{g} \exp \left(\mathrm{X}_{\text {it }}^{\prime} \beta\right)
$$

where $\lambda_{0}(t)$ is the non-parametric baseline hazard function; $X_{i t}$ is a vector of covariates summarizing observed differences between individuals such as their own religious affiliation and that of their husbands as well as controls included in Table 3; and $\beta$ is a vector of parameters to be estimated. I incorporate $\mathrm{g}_{\mathrm{i}}$, a Gamma distributed random covariate with unit mean and variance $F^{2}=:$, to describe unobserved heterogeneity between birth cohorts. Alternatively I use a grouped robust variance as estimated by Lin and Wei (1989) to account for individual unobserved heterogeneity when using small cohort samples. The dependent variable in all estimates is months to a birth from either the previous birth or marriage in the case of the first birth.

\footnotetext{
${ }^{3}$ Including a covariate to control for the number of out-of- wedlock children, though significant and negative, does not change the effect of the relevant variables.
} 


\section{FAMILY SIZE AND RELIGION}

Column (1) in Table 4 presents the coefficient of the wife's religion on the estimates of family size using data from the 1985 survey. The benchmark group is non-practicing Catholics. Only those without religious affiliation have a significantly lower family size, around 5\%, than the nonpracticing. Table 5, column (1), presents the predicted family size by wife's religion for a benchmark individual with low secondary education (and also husband's), who has been married for more than 15 years and lives in a rural area in Ceuta and Melilla (the region with the highest fertility apart from Andalucia). The predicted family size for all groups, except those without affiliation, is similar and around 4. Religious practice does not imply a distinctive behavior among the generations surveyed in $1985 .^{4}$

Estimates of the effects of religion on family size in the 1999 Survey are presented in columns (2) to (4) in Table 4 and in Table 6 . Column (2) in Table 5 presents the predicted family size of results in Table 4. Controls are set at the same benchmark values of column (1) except for city size that is now medium. In column (2) of Table 4 only the wife's religion is included and nonpracticing Catholic is, again, the reference group. As expected by the pronatalist influence of those denominations, both practicing Catholics and those in the other religion group have significantly higher family sizes than the rest. Families of non-practicing Catholics women are of similar size than those without affiliation.

Column (3) includes two covariates that indicate whether the husband shares the same religious affiliation of the wife and whether he is Catholic or not, if different. In column (3) both coefficients are significant and negative. This supports the hypothesis that marriage specific investments such as children are lower in heterogamous couples. The coefficient for a Catholic

\footnotetext{
${ }^{4}$ Results for the sub-sample of those born in 1950 and after are analogous.
} 
husband is, however, only marginally significant. The effect is larger and highly significant when the husband is not Catholic. Two reasons may account for this. First, given that the majority of the Spaniards still consider themselves at least nominally Catholic, the distance between spouses is likely to be wider in cases where the husband's affiliation is not Catholic. Second, since around three quarters of non-Catholic husbands in the sample have no affiliation, the expected negative effect on family size from the husband's lack of religious attachment reinforces that of the heterogeneous make up of the couple. ${ }^{5}$

Finally, column (4) includes both a covariate that indicates whether the husband's religion is different from that of the spouse and a set of interactive variables of that dummy with each wife's denomination types. Neither any of the coefficients separately or their joint test is significant. However, as indicated in Table 5, the joint test restricted to couples with a practicing Catholic wife indicates that the family size of a homogamous union of practicing Catholics is significantly larger than that of a practicing woman married to a man of another affiliation. This matches results in Lehrer (1996) who finds religiosity to play a large and significant role in predicted family size among US Catholics. Both the destabilizing effect associated with the heterogeneous composition of the marriage and the expected negative bargaining effect from a non-practicing husband explain the significant difference. Still the predicted family size of such unions, in column (2) Table 5, is larger than any other except for a homogamous union of individuals in the other religion group. This denotes the decisive woman's influence in current family planning decisions. The small sample size of Muslims and Protestants probably explains why the joint test of the interactive and

\footnotetext{
${ }^{5}$ In separate estimates, among those born in 1960 and after, only the coefficient for a non Catholic husband is significant and even larger than before-a $5.5 \%$ of the baseline size for non-practicing.
} 
the dummy of other religion fails to attain any meaningful level of significance even though the estimated negative coefficient for the interactive of this group is the largest of all.

Simulated family sizes in Table 5 show that family size has decreased extraordinarily from the 1985 to the 1999 survey. Predicted family size for non-practicing Catholic women has moved from 3.94 in the 1985 sample down to 2.5 in the 1999 Survey. ${ }^{6}$ These numbers match the sharp decrease in fertility rates in Spain during the last three decades. Homogamous unions of individuals from the other religions group have the largest predicted family size of around 2.75 followed closely by homogamous unions of practicing Catholic spouses with a predicted size of 2.65 , a $10 \%$ and a $6 \%$ higher than that of homogamous non-practicing Catholic unions respectively.

Overall, estimates reveal that women's religiosity has gained importance among Catholics as a determinant of fertility behavior. Thus, even if practice has declined in the population, it seems to have acquired a more significant value among those who consider themselves practicing Catholics. This confirms the main hypothesis of the paper. Until the mid 1970s, even if Catholicism was considered a state religion, the potential social gains from Mass attendance sustained religious practice at levels higher than in other European countries dominated by one religion (Iannaccone and Stark 1994). With the end of the Franco regime, church attendance collapsed but religious practice acquired a more relevant meaning than before, in terms of its implications for fertility. These results match those in a study of 13 OECD countries where religiosity among young Catholic women, in the context of decreasing church attendance and rising religious pluralism, increased its relevance in explaining differences in the ideal family size in 1994 (Adsera 2003).

\footnotetext{
${ }^{6}$ While there was no difference in predicted family size within cohorts in the 1985 sample, separate estimates predict a family size of 2.26 for those born in 1960 and after, around 10\% smaller than that of the entire 1999.
} 
Finally, I will comment briefly on the control variables included in the model. Predicted family size is larger when either the women or their spouses come from large families. The effect is stronger for the wife. Obviously, years of marriage increase fertility in all estimates. Size of the city of residence does not matter for the 1985 survey and only individuals living in a rural area (around $17 \%$ of the sample) have a modestly higher fertility than the rest in the 1999 Survey. In the 1985 Survey, wife's education slightly decreases fertility but husband's education has no effect. In the 1999 Survey, however, there is a U-shaped effect of education weaker for the wife but highly significant for the spouse. Husbands with either low or very high education have larger families than those with either high school or vocational degrees. A positive income effect due to higher earnings potential of husbands with college education, more relevant in a period of economic hardship in the country, should explain this finding.

\section{TIMING OF BIRTHS}

Differences in family size across religious groups described in the last section are the result of sequential decisions on childbearing that families undertake. In this section, I analyze when these differences arise: whether they are a product of overall postponement of childbearing in some religious groups or whether differences only emerge at high parity transitions. To unravel this issue I estimate Cox proportional hazard models of the transitions to the first three births both for the 1985 and the 1999 samples. Results for the religious covariates are presented in Tables 6 to 8. Estimates also include all the control variables in Table 3 -except for years of marriage- as well as some additional parity specific information. In particular, estimates for first birth include age at marriage and those for the second and third births include age at first birth. The model for second births includes as well months from marriage to first birth and the gender of the first child. The 
specification for third births includes the number of months between the first two births as well as two covariates that indicate whether the first two born are either two girls or two boys.

Over the last thirty years childbearing has progressively been postponed. Within cohorts in the 1985 Survey there are already some differences in the timing to parenthood though they are not as large as those found among cohorts in the 1999 survey. Figures 1 and 2 present the KaplanMeier estimates of the survival function of months to first birth from marriage and to second birth from first birth for separate birth cohorts in the 1999 Survey: those born either before 1960, between 1960 and 1968 or after 1968. In Figure 1, three years after marriage, around 80\% of those born before 1960, two thirds of those born between 1960 and 1968, but only slightly over 50\% of those born after 1968 had a first child. Figure 2 shows that, five years after the first birth, around two thirds of those born before 1960, half of those born in 1960-1968 and only one third of those born after 1968 had a second child. Given these differences, in the estimated models I control for unobserved heterogeneity between birth cohorts. The estimated variance of the unobserved heterogeneity parameter is highly significant in all estimates throughout Tables 6 to 8 .

Table 6 displays the hazard rates of the wife's religion in the transition to each birth for women interviewed in 1985. Religious affiliation does not seem to play a role in timing a first child in column (1). Only the coefficient for practicing Catholic is marginally significant among those born after 1950 in column (4). The estimated hazard rate for women with no religion is the lowest among all groups but yet not significant. Estimates of the transition to first birth from age 15, instead of the date of marriage, also display no differences among religious affiliation, except for a significantly higher hazard of practicing Catholics born on 1950 or after (see Appendix). This indicates an earlier entry into marriage by the youngest practicing Catholics among those 
interviewed in the 1985 SFS. This specification has the advantage that it considers the endogeneity of marriage -women may postpone marriage until they are ready to have a first child.

Interestingly, for second and third births, both the other religion group and practicing Catholics experiment faster transitions than non-practicing. The estimated hazard rates and their level of significance are much larger for the younger cohort, in columns (5) and (6), than for the complete 1985 sample, in columns (2) and (3).

Remember that, while no significant differences in family size are found for these groups with respect to non-practicing in Table 4, their predicted family size is significantly larger in Table 6 for the 1999 Survey. Since those born after 1950 were at most 35 years old at the time of the 1985 Survey, this may indicate that their childbearing cycle was far from over. Predicted family size in Table 4 is calculated for the benchmark marriage length. However, the length of marriages of women in those religious groups is larger for similar ages than for either non-practicing or those without religion. Thus with their group-specific average years of marriage, predicted family size for practicing Catholics and for women in other religions would have been larger. Their faster transitions to higher parities as well as their longer exposure to childbearing risk within a marriage would support those findings. Finally, biological constraints also bound the other groups that start childbearing later in life. The inclusion of age at marriage as a control in these models is controversial since, on the one hand, its exclusion may lead to omitted variable bias and, on the other, decisions on marriage and family are likely to be simultaneous (Lehrer 1996). Nonetheless, results in Tables 6 to 8 are robust to the exclusion of age at marriage as a control variable.

Tables 7 and 8 present the estimated hazard rates of religion variables on the transitions to the first three births for the 1999 survey. Table 7 includes measures of the wife's religious affiliation as well as two covariates that control whether the husband's religion is different than the 
wife's and that distinguish between Catholic and non-Catholic husbands. Table 8 employs covariates on a variety of religious make-ups of couples. A homogamous union of non-practicing Catholics is the benchmark for this table.

With regard to first children, practicing Catholics experience slightly faster transitions than non-practicing and those in the other religion group have the slowest transitions (Table 7, column 1). Both effects become stronger in the sample of women born after 1959 (Table 7, column 4). When both married couples and those in consensual unions are included, religiosity plays a bigger role. In those estimates, the hazard rate for practicing women in the transition to first births is notably higher than in the sample of married couples. ${ }^{7}$ Note that transitions in Table 7 are from the date of marriage and, though women in the other religion group postpone their first birth the most, they are the ones with earlier marriages. Interestingly in estimates of transition to first birth from age 15 (in the Appendix) women in the other religion group do not display any differential behavior with respect to non-practicing Catholics. Only women with their own beliefs show a relatively slower transition from age 15, both for the complete sample and among those born on 1960 or after. Since no difference is found when the model is estimated from the date of first marriage, this indicates a relative slower transition to marriage of women with their own beliefs.

With respect to the husband's religion, only that of Catholic husbands is positive and marginally significant, at $15 \%$.

\footnotetext{
${ }^{7}$ Higher religiosity is associated with a lower probability of entering in cohabitation (Thornton et al. 2002, Lehrer 2004) as well as with more marital births and lower incidence of premarital sex (Petersen and Donnenwerth 1997). Results are available from the author.
} 
In Table 8, homogamous practicing Catholic couples, practicing women married to nonpracticing men and Catholic men married to women without affiliation (a very small group) become parents within their marriages at a faster rate than homogamous couples without affiliation.

In estimates for the second child, the other religion group experiences the fastest transitions in column (2), especially when the sample is restricted to women born after 1959 in column (4), when the estimated hazard rate is above 2. Both practicing Catholic women and those with own beliefs have faster transitions than the baseline group. As expected, if the husband's religion is different than the wife's, transitions are slower, but only for the case of a Catholic husband. Overall, the net effects across religious denominations for the second child do not seem to be very large, except for those in the other religion group. An analysis of results in Table 8 shows that only homogamous couples of practicing Catholics and, at only marginal 15\% significance, those with at least one spouse in the other religion group show a differentially faster transition to second birth than any other category. The hazard ratio for practicing Catholics is not too large.

Estimates for third births clearly portray a dissimilar behavior across groups. First, those on the other religion group, mostly Muslims and conservative Protestants, who on average are the lowest educated group in the sample, transit distinctively fast to a third child. Second, practicing Catholics follow at a significantly faster speed than any of the other groups. Only in column (6) in Table 7, those with no beliefs portray a marginally significantly higher hazard. The extremely reduced sample size of that group may be responsible for that unexpected finding. Finally, hazard rates for a husband with a different religion -both Catholic and non-Catholic- are well below one. Estimates are highly significant for those heterogamous couples with a non-Catholic husband. The hazard rate for the complete sample is already 0.61, but that for those born in 1960 and after only 
reaches 0.246 . The marital stability or compatibility effect seems to be working strongly when couples face the decision of a third child.

Table 8 confirms those results. Homogamous practicing Catholic couples and those with one spouse in the other religion group transit notably faster to third births. Couples with a practicing Catholic husband and a non-practicing wife display a high hazard rate, only marginally significant at $15 \%$. This result completes the findings in Table 7 by providing evidence that religious practice among husbands, when differences in the couple's religious background are not too large, also matters for fertility in modern Spain.

To sum up, differences of total family size do not seem to arise from differential postponement of parenthood within marriages. However, differences in the timing of household formation across religious affiliation are guaranteed to play a role in determining age at first marital birth and, as a result, affect the complete family history of childbearing. Still, differential behavior in the transition to third births decisively shapes family sizes. Two forces dominate the dynamics of third births, first, a positive effect from more pronatalist churches and, second, a negative effect on spouse specific investment from heterogamous couples.

Finally, it is worth reviewing the effect of control variables in the estimates. The size of the city of residence does not affect any of the transitions. A wife with a large family transits faster to a birth of any order in Table 6 . Highly educated couples postpone first birth the most but transit the fastest to a second child. Obviously, the negative effect of education on first births is even stronger if the considered time frame starts at age 15 . The effect of education on third births has changed over birth cohorts. While in the analysis of the 1985 Survey a husband's education is irrelevant and the lowest educated women transit significantly faster than all the rest to a third child, in recent years the effect of husband's education (and to some extent the wife's) and third births is U- 
shaped. ${ }^{8}$ Among those born after 1959, a husband with a four-year college degree is associated with the fastest transitions. Economic uncertainty since the 1980s in Spain has constrained childbearing choices for many couples. Higher earnings among those with tertiary education help in long-term family planning investments such as children. Age at first birth (or age at marriage) decreases hazard to all transitions. The gender of the first child has no impact in transition to second births in 1985 but families whose first-born is a boy transit faster to a second birth in the complete sample of 1999 (column 2 in Table 7). Covariates that indicate whether the first two children are either two girls or two boys are highly significant in all third birth estimates, except for families with two girls in column (3) of Table 7, denoting that a taste for variety increases the hazard to a third birth.

\section{CONCLUSIONS}

In this paper I have used information on religious affiliation and religiosity from the 1985 and 1999 Spanish Fertility Surveys to study whether recent changes in the country's religious landscape, mainly a dramatic drop in church attendance, translate in differential fertility behavior among groups. I estimate family size for different religious affiliation of the woman as well as different religious make-up of the couple. Results confirm the main hypothesis laid out in the paper.

First, while among those surveyed in 1985 there were no significant differences in family size among practicing and non-practicing Catholics, practicing Catholics portray significantly higher fertility during recent years. I argue that, since the onset of democracy in 1975 and with the disappearance of social gains from Mass attendance, a better sorting among Spanish Catholics is responsible for this finding. Even if rates of church participation have decreased dramatically,

\footnotetext{
${ }^{8}$ A similar nonlinear relationship of education and third births in Europe has already been found in the literature (Hoem and Hoem 1989, Kravdal 2001, Adsera 2004 b).
} 
religiosity has acquired a more relevant meaning than before in terms of its implications for demographic behavior. Second, individuals in small denominations such as Muslims and Conservative protestants within an, otherwise, homogeneous religious landscape are likely committed to their pronatalist affiliation and have more children on average. Finally, confirming previous results in the literature, inter-faith marriages display lower fertility than homogamous unions, particularly when the husband is not Catholic. Conflicting preferences as well as perceived relative frailty of the union are potential explanations for the low level of union-specific investments, such as children, among those couples.

To determine the mechanisms through which family size differences arise, that is whether they are a product of overall postponement of childbearing in some religious groups or whether differences only emerge at high parity transitions, I estimate Cox proportional hazard models of the transitions to the first three births. Minor differences in transition to motherhood within marriage, faster among practicing Catholics, have arisen in recent years while the spacing of the second child is relatively homogeneous across groups. Still, two forces dominate the dynamics of third births and decisively shape family sizes: a faster transition from individuals of more pronatalist churches, practicing Catholics and those in small denominations, and a remarkable slow progression among inter-faith couples, particularly those with a non-Catholic husband. 
APPENDIX. Estimated Hazard Ratio from Cox Proportional model of transition to first birth from age 15 .

\begin{tabular}{|c|c|c|c|c|}
\hline & \multicolumn{2}{|c|}{1985 SFS } & \multicolumn{2}{|c|}{1999 SFS } \\
\hline & All & Born 1950+ & All & Born 1960+ \\
\hline $\begin{array}{l}\text { Wife's Religion } \\
\text { (Non-Practicing Catholic) }\end{array}$ & & & & \\
\hline Practicing Catholic & $\begin{array}{l}0.999 \\
(-0.03)\end{array}$ & $\begin{array}{l}1.110 \\
(2.06) * *\end{array}$ & $\begin{array}{l}0.979 \\
(-0.67)\end{array}$ & $\begin{array}{l}1.011 \\
(0.23)\end{array}$ \\
\hline Other Religion & $\begin{array}{l}0.905 \\
(-0.75)\end{array}$ & $\begin{array}{l}0.981 \\
(-0.08)\end{array}$ & $\begin{array}{l}0.878 \\
(-1.16)\end{array}$ & $\begin{array}{l}0.894 \\
(-0.67)\end{array}$ \\
\hline No Beliefs & $\begin{array}{l}0.900 \\
(-1.01)\end{array}$ & $\begin{array}{l}0.950 \\
(-0.35)\end{array}$ & $\begin{array}{l}0.965 \\
(-0.42)\end{array}$ & $\begin{array}{l}0.935 \\
(-0.59)\end{array}$ \\
\hline Own Beliefs & & & $\begin{array}{l}0.833 \\
(-2.30)^{* *}\end{array}$ & $\begin{array}{l}0.847 \\
(-1.46) \#\end{array}$ \\
\hline Subjects & 8,681 & 4,917 & 7,514 & 5,049 \\
\hline Failures & 5,094 & 2,005 & 4,603 & 2,381 \\
\hline Log Likelihood & -41886 & -15212 & -36512 & -17734 \\
\hline Variance Unobs. Heterog. & $0.008 * *$ & & $0.135^{* *}$ & \\
\hline
\end{tabular}

Note: Models include all control variables for the woman in Table 3 except years of marriage. Tstatistics in brackets.

$\# \mathbf{p}<0.15,{ }^{*} \mathbf{p}<0.10, * * \mathbf{p}<0.05$. 


\section{REFERENCES}

Adsera, A. 2003. Religion and Changes in Family-size Norms in Developed Countries, mimeo, University of Illinois at Chicago. 2004 a. "Changing Fertility Rates in Developed Markets. The Impact of Labor

Market Institutions.” Journal of Population Economics 17: 17-43. . 2004 b. "Where Are the Babies? Labor Market Conditions and Fertility in Europe."

Population Research Center, University of Chicago. http://ssrn.com/abstract=530242

Adam, P. 1996. "Mothers in an insider-outsider economy: The puzzle of Spain.” Journal of Population Economics 9:301-323.

Ahn, N. and P. Mira. 2001. "Job bust, baby bust? Evidence from Spain.” Journal of Population Economics 14:505-521.

Barro, R. J. and R.M. McCleary. 2003. "Religion and Economic Growth.” NBER Working Paper No. W9682. http://ssrn.com/abstract=406054

Branas, P and S. Neuman. 2004. “Analyzing Religiosity Within an economic Framework: The Case of Spanish Catholics.” Review of Economics of the Household 2 (1): 5-22.

Becker, G. 1991. A Treatise on the Family, Harvard University Press, Cambridge, MA.

Becker, G., E. Landes and R. Michael. 1977. “An Economic Analysis of Marital Instability.” Journal of Political Economy 85 (6): 1141-1187.

Becker, G. and K. Murphy. 2001. Social Economics: Market Behavior in a Social Environment, Harvard University Press, Cambridge, MA.

Bumpass, L. 1990. "What's Happening to the Family? Interactions Between Demographic and Institutional Change.” Demography 27 (4): 483-498. 
Chiswick, B.R. 1988. "Differences in Education and Earnings Across Racial and Ethnic Groups: Tastes, Discrimination, and Investments in Child Quality." Quarterly Journal of Economics 103 (3): 571-597.

Goldscheider, C. and W.D. Mosher. 1991. "Patterns of contraceptive use in the United States: The importance of religious factors." Studies in Family Planning 22 (2): 102-115.

Gutierrez-Domenech, M. 2002. "The Impact of the Labor Market on the Timing of Marriage and Births in Spain." CEP working paper.

Hoem, B. and J. Hoem. 1989. “The Impact of Women's Employment on Second and Third Births in Modern Sweden.” Population Studies 43: 47-67.

Iannaccone, L. and R. Stark. 1994. “A Supply -side reinterpretation of the "secularization" of Europe." Journal of the Scientific Study of Religion, 76-88.

Instituto Nacional de Estadistica (INE) 1985. Encuesta de Fecundidad 1985, Madrid. 1999. Encuesta de Fecundidad 1999, Madrid.

Kravdal, O. 2001. "The High Fertility of College Educated Women in Norway." Demographic

Research 5.

Lehrer, E.L. 1996. "Religion as a determinant of marital fertility." Journal of Population Economics 9: 173-196. 1999. 'Religion as a Determinant of Educational Attainment: An Economic

Perspective." Social Science Research 28: 358-379. . 2004. "The Role of Religion in Union Formation: An Economic Perspective."

Population Research and Policy Review 23: 161-185.

Lehrer, E. L. and C. U. Chiswick. 1993. "Religion as a Determinant of Marital Stability." Demography 30 (3): 385-404. 
Lesthaeghe, R. and J. Surkyn. 1988. "Cultural Dynamics and Economic Theories of Fertility Change." Population and Development Review 14 (1): 1-45.

Morgan, S., S. Stash, H. L. Smith and K. O. Mason. 2002. "Muslim and Non-Muslim Differences in Female Autonomy and Fertility: Evidence from Four Asian Countries." Population and Development Review 28 (3): 515-537, September.

Mosher, W. and G. Hendershot. 1984. "Religion and Fertility: A Replication.” Demography 21 (2): 185-191.

Mosher W., D. Johnson, \& M. Horn. 1986. "Religion and Fertility in the United States: The Importance of Marriage Patterns and Hispanic Origin.” Demography 23 (3): 367-379.

O Grada, C. \& B. Walsh. 1995. "Fertility and Population in Ireland, North and South.” Population Studies 49 (2): 259-279.

Petersen, L.R. and G.V. Donnenwerth 1997. "Secularization and the influence of religion on beliefs about premarital sex." Social Forces 75 (3): 1071-1089.

Sacerdote, B. and E. Glaeser. 2001. "Education and Religion.” NBER working paper N. 8080.

Sander, W. 1992. "Catholicism and the Economics of Fertility." Population Studies 46, p.477-489. 1993. "Catholicism and Marriage in the United States.” Demography 30 (3): 373-384.

Surkyn, J. and R. Lesthaeghe. 2004. "Values Orientations and the Second Demographic Transition (STD) in northern, western and southern Europe: an update." Demographic Research, Special collection 3 , article 3 .

Thornton, A, W.G. Axinn and D. H. Hill. 1992. "Reciprocal effects of religiosity, cohabitation and marriage." American Journal of Sociology 98 (3): 628-651.

United Nations. 2002. World Contraceptive Use 2001. Population Division of the Department of Economic and Social Affairs of the United Nations Secretariat, New York. 
Van de Kaa, D. 1987. “Europe's Second Demographic Transition.” Population Bulletin 42:

$1-57$.

Westoff, Ch. and E.F.Jones. 1979. "The End of Catholic Fertility.” Demography 16 (2): 209-217.

Williams, L.B. and B.G. Zimmer. 1990. "The Changing Influence of Religion on US Fertility:

Evidence from Rhode Island.” Demography 27 (3): 475-481. 
Table 1. Means of Religion Variables. 1985 Spanish Fertility Survey.

\begin{tabular}{lcc}
\hline & Married & Born 1950+ \\
\hline Wife 's Religion & & \\
Practicing Catholic & 0.612 & 0.491 \\
Non-Practicing Catholic & 0.358 & 0.469 \\
Other religion & 0.011 & 0.013 \\
No Religion & 0.019 & 0.027 \\
& & \\
N. Observations & 5437 & 2220 \\
\end{tabular}


Table 2. Means of Religion Variables. 1999 Spanish Fertility Survey.

\begin{tabular}{|c|c|c|}
\hline & All & Born 1960+ \\
\hline \multicolumn{3}{|l|}{ Wife's Religion } \\
\hline Practicing Catholic & 0.432 & 0.366 \\
\hline Non-Practicing Catholic & 0.488 & 0.543 \\
\hline Other Religion & 0.020 & 0.024 \\
\hline No Beliefs & 0.028 & 0.029 \\
\hline Own Beliefs & 0.032 & 0.037 \\
\hline \multicolumn{3}{|l|}{ Husband's Religion } \\
\hline Same as Wife & 0.847 & 0.853 \\
\hline Different and Catholic & 0.105 & 0.095 \\
\hline Different and not Catholic & 0.048 & 0.052 \\
\hline \multicolumn{3}{|l|}{ Interaction } \\
\hline Wife Catholic $\mathrm{P} *$ husb. different & 0.092 & 0.080 \\
\hline Wife Other $*$ husb. different & 0.002 & 0.002 \\
\hline Wife No Beliefs * husb. different & 0.012 & 0.016 \\
\hline Wife Own Beliefs * husb. different & 0.011 & 0.015 \\
\hline \multicolumn{3}{|l|}{ Alternative Variables } \\
\hline Both Catholic Practice & 0.339 & 0.287 \\
\hline Both Catholic No Practice & 0.448 & 0.501 \\
\hline W. Cath. Practice/Husb. Cath No Practice & 0.085 & 0.072 \\
\hline W. Cath. Practice/Husb. No Affiliation & 0.006 & 0.006 \\
\hline W. Cath. No Practice/Husb. Cath. Practice & 0.010 & 0.009 \\
\hline W. Cath. No Practice/Husb. No Affiliation & 0.023 & 0.024 \\
\hline W. No Affiliation/Husb Catholic & 0.009 & 0.013 \\
\hline At least one Other Religion & 0.023 & 0.028 \\
\hline Both No Affiliation & 0.058 & 0.061 \\
\hline N. Observations & 4346 & 2344 \\
\hline
\end{tabular}


Table 3. Control Variables

\begin{tabular}{|c|c|c|}
\hline & 1985 SFS & 1999 SFS \\
\hline \multicolumn{3}{|l|}{ Duration of Marriage (years) } \\
\hline $0-2$ & 0.072 & 0.057 \\
\hline $3-4$ & 0.061 & 0.066 \\
\hline $5-6$ & 0.074 & 0.072 \\
\hline $7-8$ & 0.086 & 0.077 \\
\hline $9-10$ & 0.092 & 0.081 \\
\hline $11-12$ & 0.093 & 0.081 \\
\hline $13-14$ & 0.091 & 0.084 \\
\hline 15 or more & $(0.431)$ & $(0.482)$ \\
\hline \multicolumn{3}{|l|}{ Family Background } \\
\hline Wife 2+ sibling & 0.425 & n.a.* \\
\hline Husband 2+ siblings & 0.453 & n.a.* \\
\hline \multicolumn{3}{|l|}{ Size of City } \\
\hline Rural & $(0.558)$ & 0.172 \\
\hline Small & 0.223 & 0.246 \\
\hline Medium & & $(0.463)$ \\
\hline Large & 0.219 & 0.119 \\
\hline \multicolumn{3}{|l|}{ Wife's Education } \\
\hline No Studies & 0.164 & 0.034 \\
\hline Primary & 0.483 & 0.240 \\
\hline Low Secondary & $(0.191)$ & $(0.314)$ \\
\hline High School & 0.090 & 0.121 \\
\hline Vocational & & 0.148 \\
\hline College (2 y.) & 0.052 & 0.067 \\
\hline College (4 y.) & 0.021 & 0.076 \\
\hline \multicolumn{3}{|l|}{ Husband's Education } \\
\hline No Studies & 0.128 & 0.032 \\
\hline Primary & 0.440 & 0.219 \\
\hline Low Secondary & $(0.175)$ & $(0.305)$ \\
\hline High School & 0.156 & 0.133 \\
\hline Vocational & & 0.153 \\
\hline College (2 y.) & 0.051 & 0.061 \\
\hline College (4 y.) & 0.050 & 0.098 \\
\hline \multicolumn{3}{|l|}{ Region of Residence } \\
\hline Andalucia & 0.107 & 0.151 \\
\hline Aragon & 0.042 & 0.045 \\
\hline Asturias & 0.041 & 0.037 \\
\hline Cantabria & 0.033 & 0.023 \\
\hline
\end{tabular}




\begin{tabular}{lcc}
\hline Castilla La Mancha & 0.053 & 0.048 \\
Castilla Leon & 0.062 & 0.070 \\
Catalunya & 0.107 & 0.095 \\
Extremadura & 0.041 & 0.043 \\
Galicia & 0.069 & 0.074 \\
Baleares & 0.035 & 0.026 \\
Canarias & 0.045 & 0.060 \\
La Rioja & 0.034 & 0.025 \\
Madrid & 0.083 & 0.083 \\
Murcia & 0.043 & 0.051 \\
Navarra & 0.036 & 0.025 \\
Pais Vasco & 0.058 & 0.043 \\
Valencia & 0.081 & 0.075 \\
Ceuta Melilla & $(0.031)$ & $(0.026)$ \\
& & \\
N. Observations & 5437 & 4346 \\
\hline
\end{tabular}

Note: Benchmark values in parentheses. Family background information is not available in the 1999 SFS. 
Table 4. Religion and Family Size (1985 and 1999 SFS)

\begin{tabular}{|c|c|c|c|c|}
\hline & 1985 SFS & & 1999 SFS & \\
\hline & (1) & (2) & (3) & (4) \\
\hline \multicolumn{5}{|l|}{$\begin{array}{l}\text { Wife's Religion } \\
\text { (Non-Practicing Catholic) }\end{array}$} \\
\hline Practicing Catholic & $\begin{array}{l}-0.012 \\
(-0.34)\end{array}$ & $\begin{array}{l}0.130 \\
(4.52)^{* *}\end{array}$ & $\begin{array}{l}0.139 \\
(4.59)^{* *}\end{array}$ & $\begin{array}{l}0.151 \\
(4.75)^{* *}\end{array}$ \\
\hline Other Religion & $\begin{array}{l}0.121 \\
(0.79)\end{array}$ & $\begin{array}{l}0.228 \\
(1.96) *\end{array}$ & $\begin{array}{l}0.229 \\
(1.96) *\end{array}$ & $\begin{array}{l}0.254 \\
(2.00)^{* *}\end{array}$ \\
\hline No Beliefs & $\begin{array}{l}-0.205 \\
(-1.70)^{*}\end{array}$ & $\begin{array}{l}-0.065 \\
(-0.87)\end{array}$ & $\begin{array}{l}-0.052 \\
(-0.69)\end{array}$ & $\begin{array}{l}-0.050 \\
(-0.57)\end{array}$ \\
\hline Own Beliefs & & $\begin{array}{l}-0.062 \\
(-0.85)\end{array}$ & $\begin{array}{l}-0.040 \\
(-0.54)\end{array}$ & $\begin{array}{l}-0.044 \\
(-0.48)\end{array}$ \\
\hline \multicolumn{5}{|l|}{$\begin{array}{l}\text { Husband's Religion } \\
\text { (Same as Wife) }\end{array}$} \\
\hline Different (any) & & & & $\begin{array}{l}-0.041 \\
(-0.70)\end{array}$ \\
\hline Different and Catholic & & & $\begin{array}{l}-0.074 \\
(-1.62) \#\end{array}$ & \\
\hline Different and not Catholic & & & $\begin{array}{l}-0.115 \\
(-2.08) * *\end{array}$ & \\
\hline \multicolumn{5}{|l|}{ Interaction } \\
\hline Wife P. Catholic * husb. different & & & & $\begin{array}{l}-0.068 \\
(-0.88)\end{array}$ \\
\hline Wife Other $*$ husb. different & & & & $\begin{array}{l}-0.225 \\
(-0.79)\end{array}$ \\
\hline Wife No Beliefs * husb. different & & & & $\begin{array}{l}-0.033 \\
(-0.19)\end{array}$ \\
\hline Wife Own Beliefs * husb. different & & & & $\begin{array}{l}-0.025 \\
(-0.16)\end{array}$ \\
\hline Constant & $\begin{array}{l}3.934 \\
(33.9)^{* *}\end{array}$ & $\begin{array}{l}2.500 \\
(25.70)^{* *}\end{array}$ & $\begin{array}{l}2.510 \\
(25.75)^{* *}\end{array}$ & $\begin{array}{l}2.502 \\
(25.43) * *\end{array}$ \\
\hline Adjusted $\mathrm{R}^{2}$ & 0.346 & 0.312 & 0.313 & 0.313 \\
\hline $\begin{array}{l}\text { F (2) Husb. Religion Variables } \\
\text { F (6) Husb Religion Variables }\end{array}$ & & & $3.25 * *$ & 127 \\
\hline Sample Size & 5,437 & 4,346 & 4,346 & 4,346 \\
\hline
\end{tabular}

Note: Ordinary least squares with robust errors. Regressions include all control variables in Table 3. T-statistics in brackets.

$\# \mathrm{p}<0.15, * \mathrm{p}<0.10, * * \mathrm{p}<0.05$. 
Table 5. Predicted Family Size by Wife's Religion

\begin{tabular}{lll}
\hline & 1985 SFS & 1999 SFS \\
\hline $\begin{array}{l}\text { Wife's Religion } \\
\text { (based on Cols. 1 \& 2) }\end{array}$ & \\
Non-Practicing Catholic vs. & 3.939 & 2.500 \\
Practicing Catholic & 3.927 & $2.630^{* *}$ \\
Other Religion & 4.060 & $2.728^{*}$ \\
No Beliefs & $3.734^{*}$ & 2.435 \\
Own Beliefs & & 2.438 \\
& \\
Homogamous Union & & \\
(based on Col. 4) & & 2.502 \\
Both Non-Practicing Catholic vs. & $2.653^{* *}$ \\
Both Practicing Catholic & $2.756^{* *}$ \\
Both Other Religion & 2.452 \\
Both No Beliefs & 2.458 \\
Both Own Beliefs & \\
Heterogamous Union & \\
(based on Col. 4) & & \\
Both Non-Practicing Catholic vs. & \\
Wife Non-Practicing Catholic, husb. different & 2.505 \\
Both Practicing Catholic vs. & 2.461 \\
Wife Practicing Catholic, husb. Different & 2.452 \\
Both Other Religion vs. & 2.653 \\
Wife Other, husb. different & \\
Both No Beliefs vs. & \\
Wife No Beliefs, husb. different & \\
Both Own Beliefs vs. & $2.393^{*}$ \\
Wife Own Beliefs, husb. different & \\
\hline
\end{tabular}

Note: Predicted family size is based on results in Table 4 by setting the controls to benchmark values. $\# \mathrm{p}<0.15, * \mathrm{p}<0.10, * * \mathrm{p}<0.05$. 
Table 6. Estimated Hazard Ratios from Cox Proportional Model of Transitions to First, Second and Third Child (1985 SFS)

\begin{tabular}{|c|c|c|c|c|c|c|}
\hline \multirow[b]{2}{*}{ Parity } & \multicolumn{3}{|l|}{ All } & \multicolumn{3}{|c|}{ Born 1950+ } \\
\hline & First & Second & Third & First & Second & Third \\
\hline & (1) & (2) & (3) & (4) & (5) & (6) \\
\hline $\begin{array}{l}\text { Wife's Religion } \\
\text { (Non-Practicing } \\
\text { Catholic) }\end{array}$ & & & & & & \\
\hline Practicing Catholic & $\begin{array}{l}1.046 \\
(1.31)\end{array}$ & $\begin{array}{l}1.126 \\
(2.90)^{* *}\end{array}$ & $\begin{array}{l}1.172 \\
(2.58) * *\end{array}$ & $\begin{array}{l}1.091 \\
(1.64) \#\end{array}$ & $\begin{array}{l}1.192 \\
(2.43)^{* *}\end{array}$ & $\begin{array}{l}1.278 \\
(1.78)^{*}\end{array}$ \\
\hline No Religion & $\begin{array}{l}0.889 \\
(-0.96)\end{array}$ & $\begin{array}{l}0.871 \\
(-0.85)\end{array}$ & $\begin{array}{l}0.957 \\
(-0.17)\end{array}$ & $\begin{array}{l}0.844 \\
(-1.17)\end{array}$ & $\begin{array}{l}0.711 \\
(-1.35)\end{array}$ & $\begin{array}{l}0.831 \\
(-0.34)\end{array}$ \\
\hline Other Religion & $\begin{array}{l}1.008 \\
(0.05)\end{array}$ & $\begin{array}{l}1.292 \\
(1.52) \#\end{array}$ & $\begin{array}{l}1.494 \\
(1.63) \#\end{array}$ & $\begin{array}{l}1.223 \\
(0.90)\end{array}$ & $\begin{array}{l}1.669 \\
(2.11)^{* *}\end{array}$ & $\begin{array}{l}2.705 \\
(2.67)^{* *}\end{array}$ \\
\hline Subjects & 5,229 & 4,345 & 3,279 & 2,149 & 1,656 & 1,011 \\
\hline Failures & 4,466 & 3,264 & 1,521 & 1,756 & 997 & 297 \\
\hline Log Likelihood & -35142 & -24952 & -11308 & -12178 & -6631 & -1790 \\
\hline $\begin{array}{l}\text { Variance Unobs. } \\
\text { Heterog. }\end{array}$ & $0.002 *$ & $0.135^{* *}$ & $0.135 * *$ & & & \\
\hline
\end{tabular}

Note: Models include all control variables in Table 3, except years of marriage, as well as some parity specific information. T-statistics in brackets. \# $\mathrm{p}<0.15, * \mathrm{p}<0.10, * * \mathrm{p}<0.05$. Gamma frailty shared over birth cohorts (born 1935-46, 1947-55, 1955-67). 
Table 7. Estimated Hazard Ratios from Cox Proportional Model of Transitions to First, Second and Third Child. (1999 SFS)

\begin{tabular}{|c|c|c|c|c|c|c|}
\hline \multicolumn{4}{|c|}{ All } & \multicolumn{3}{|c|}{ Born 1960+ } \\
\hline Parity & First & Second & Third & First & Second & Third \\
\hline $\begin{array}{l}\text { Wife's Religion } \\
\text { (Non-Practicing } \\
\text { Catholic) } \\
\text { Practicing }\end{array}$ & (1) & (2) & (3) & (4) & (5) & (6) \\
\hline Catholic & $\begin{array}{l}1.069 \\
(1.82)^{*}\end{array}$ & $\begin{array}{l}1.148 \\
(3.18)^{* *}\end{array}$ & $\begin{array}{l}1.404 \\
(4.10)^{* *}\end{array}$ & $\begin{array}{l}1.115 \\
(2.04)^{* *}\end{array}$ & $\begin{array}{l}1.227 \\
(3.02)^{* *}\end{array}$ & $\begin{array}{l}1.415 \\
(2.10)^{* *}\end{array}$ \\
\hline Other Religion & $\begin{array}{l}0.769 \\
(-1.94) *\end{array}$ & $\begin{array}{l}1.360 \\
(1.96)^{*}\end{array}$ & $\begin{array}{l}2.083 \\
(3.06) * *\end{array}$ & $\begin{array}{l}0.692 \\
(-1.90) *\end{array}$ & $\begin{array}{l}2.278 \\
(3.87)^{* *}\end{array}$ & $\begin{array}{l}1.915 \\
(1.87)^{*}\end{array}$ \\
\hline No Beliefs & $\begin{array}{l}0.874 \\
(-1.29)\end{array}$ & $\begin{array}{l}0.926 \\
(-0.58)\end{array}$ & $\begin{array}{l}1.126 \\
(0.42)\end{array}$ & $\begin{array}{l}0.920 \\
(-0.62)\end{array}$ & $\begin{array}{l}1.202 \\
(0.82)\end{array}$ & $\begin{array}{l}1.984 \\
(1.60) \#\end{array}$ \\
\hline Own Beliefs & $\begin{array}{l}0.910 \\
(-0.96)\end{array}$ & $\begin{array}{l}1.257 \\
(1.93)^{*}\end{array}$ & $\begin{array}{l}0.949 \\
(-0.20)\end{array}$ & $\begin{array}{l}0.990 \\
(-0.07)\end{array}$ & $\begin{array}{l}1.292 \\
(1.66)^{*}\end{array}$ & $\begin{array}{l}1.280 \\
(0.61)\end{array}$ \\
\hline $\begin{array}{l}\text { Husband's } \\
\text { Religion } \\
\text { (Same as Wife) } \\
\text { Different and }\end{array}$ & & & & & & \\
\hline Catholic & $\begin{array}{l}1.088 \\
(1.53) \#\end{array}$ & $\begin{array}{l}0.900 \\
(-1.61) \#\end{array}$ & $\begin{array}{l}0.834 \\
(-1.44)\end{array}$ & $\begin{array}{l}1.109 \\
(1.24)\end{array}$ & $\begin{array}{l}0.814 \\
(-1.97) *\end{array}$ & $\begin{array}{l}0.690 \\
(-1.25)\end{array}$ \\
\hline $\begin{array}{l}\text { Different and not } \\
\text { Catholic }\end{array}$ & $\begin{array}{l}1.029 \\
(0.36)\end{array}$ & $\begin{array}{l}1.012 \\
(0.13)\end{array}$ & $\begin{array}{l}0.614 \\
(-2.16)^{* *}\end{array}$ & $\begin{array}{l}1.039 \\
(0.36)\end{array}$ & $\begin{array}{l}1.043 \\
(0.28)\end{array}$ & $\begin{array}{l}0.246 \\
(-2.49) * *\end{array}$ \\
\hline Subjects & 4,250 & 3,763 & 2,737 & 2,308 & 1,921 & 1,182 \\
\hline Failures & 3,804 & 2,696 & 756 & 1,949 & 1,145 & 200 \\
\hline $\begin{array}{l}\text { Log Likelihood } \\
\text { Variance Unobs. } \\
\text { Heterog. }\end{array}$ & $\begin{array}{l}-28417 \\
0.135 * *\end{array}$ & $\begin{array}{l}-19992 \\
0.135 * *\end{array}$ & $\begin{array}{l}-5428 \\
0.062 * *\end{array}$ & -13361 & -7668 & -1211 \\
\hline
\end{tabular}

Note: Models include all control variables in Table 3, except years of marriage, as well as some parity specific information.. T-statistics in brackets. \# $\mathrm{p}<0.15, * \mathrm{p}<0.10, * * \mathrm{p}<0.05$. Gamma frailty shared over birth cohorts (born before 60, 60-68, after 68). 
Table 8. Estimated Hazard Ratios from Cox Proportional Model of Transitions to First, Second and Third Child (1999 SFS)

\begin{tabular}{llll}
\hline Parity & First & Second & Third \\
\hline Couple's Religion & & & \\
(Both Non-Practicing Catholic) & & & \\
Both Practicing Catholic & & & \\
& 1.072 & 1.141 & 1.464 \\
W. Practicing Cath./Husb. Non-Practicing Cath & $(1.82)^{*}$ & $(2.93)^{* *}$ & $(4.50)^{* *}$ \\
& 1.138 & 1.057 & 1.159 \\
W. Practicing Cath./Husb. No Affiliation & $(2.09)^{* *}$ & $(0.77)$ & $(1.04)$ \\
& 1.187 & 1.054 & 0.733 \\
W. Non-Practicing Cath./Husb. Practicing Cath. & $(0.75)$ & $(0.19)$ & $(-0.53)$ \\
& 1.019 & 0.933 & 1.736 \\
W. Non-Practicing Cath./Husb. No Affiliation & $(0.12)$ & $(-0.34)$ & $(1.52) \#$ \\
W. No Affiliation/Husb Catholic & 1.084 & 1.068 & 0.732 \\
& $(0.73)$ & $(0.50)$ & $(-1.00)$ \\
At least one Other Religion & 1.544 & 0.805 & 0.717 \\
& $(2.45)^{* *}$ & $(-0.93)$ & $(-0.65)$ \\
Both No Affiliation & 0.794 & 1.244 & 1.949 \\
& $(-1.84)^{*}$ & $(1.48) \#$ & $(2.85)^{* *}$ \\
Subjects & 0.825 & 1.115 & 1.052 \\
Failures & $(-2.36)^{* *}$ & $(1.09)$ & $(0.23)$ \\
Log Likelihood & & & \\
Variance Unobs. Heterog. & 4,250 & 3,763 & 2,737 \\
& 3,804 & 2,696 & 756
\end{tabular}

Note: Models include all control variables in Table 3, except years of marriage, as well as some parity specific information. T-statistics in brackets. $\# \mathrm{p}<0.15, * \mathrm{p}<0.10, * * \mathrm{p}<0.05$. Gamma frailty shared over birth cohorts (born before 60, 60-68, after 68). 
Figure 1

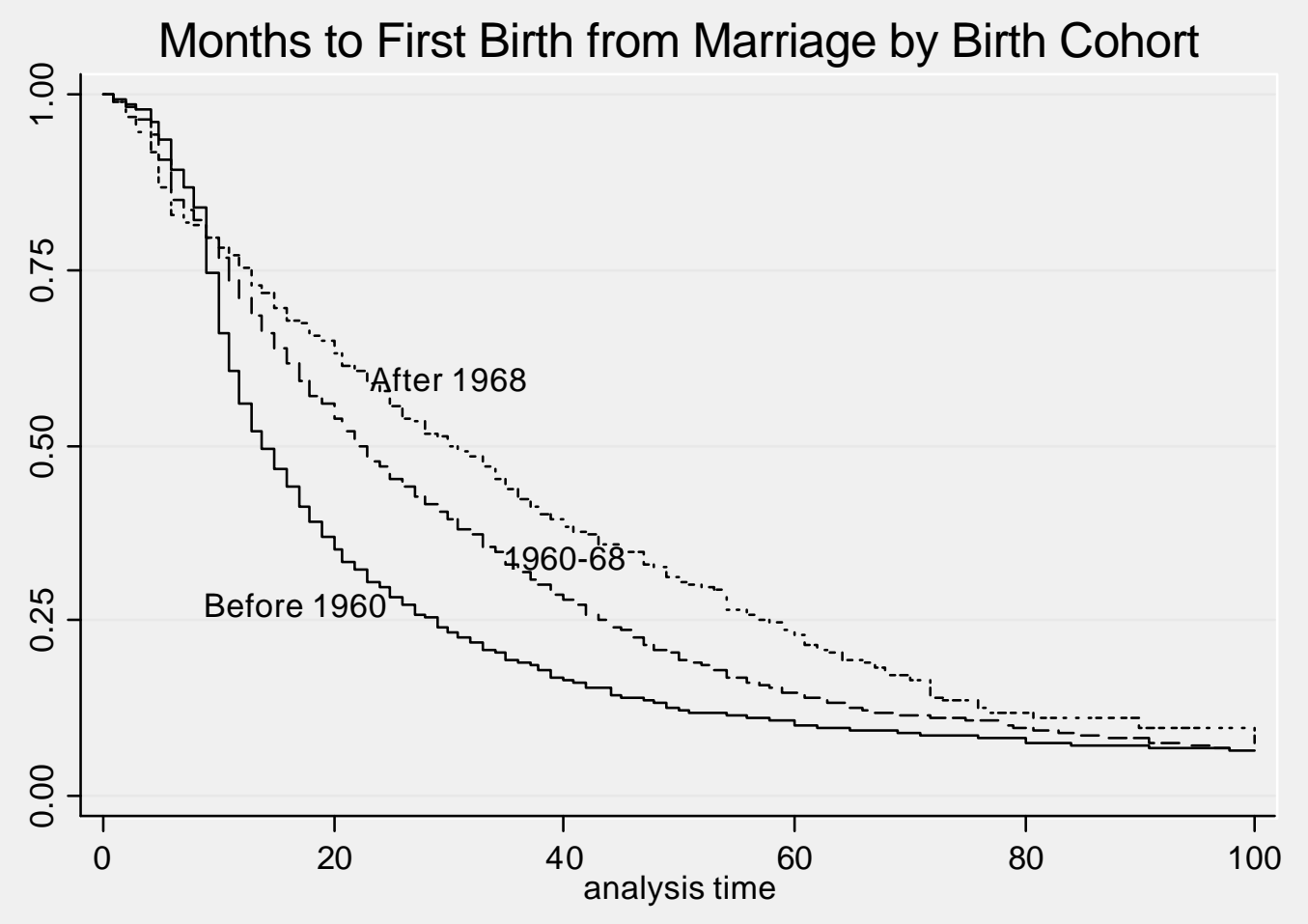


Figure 2

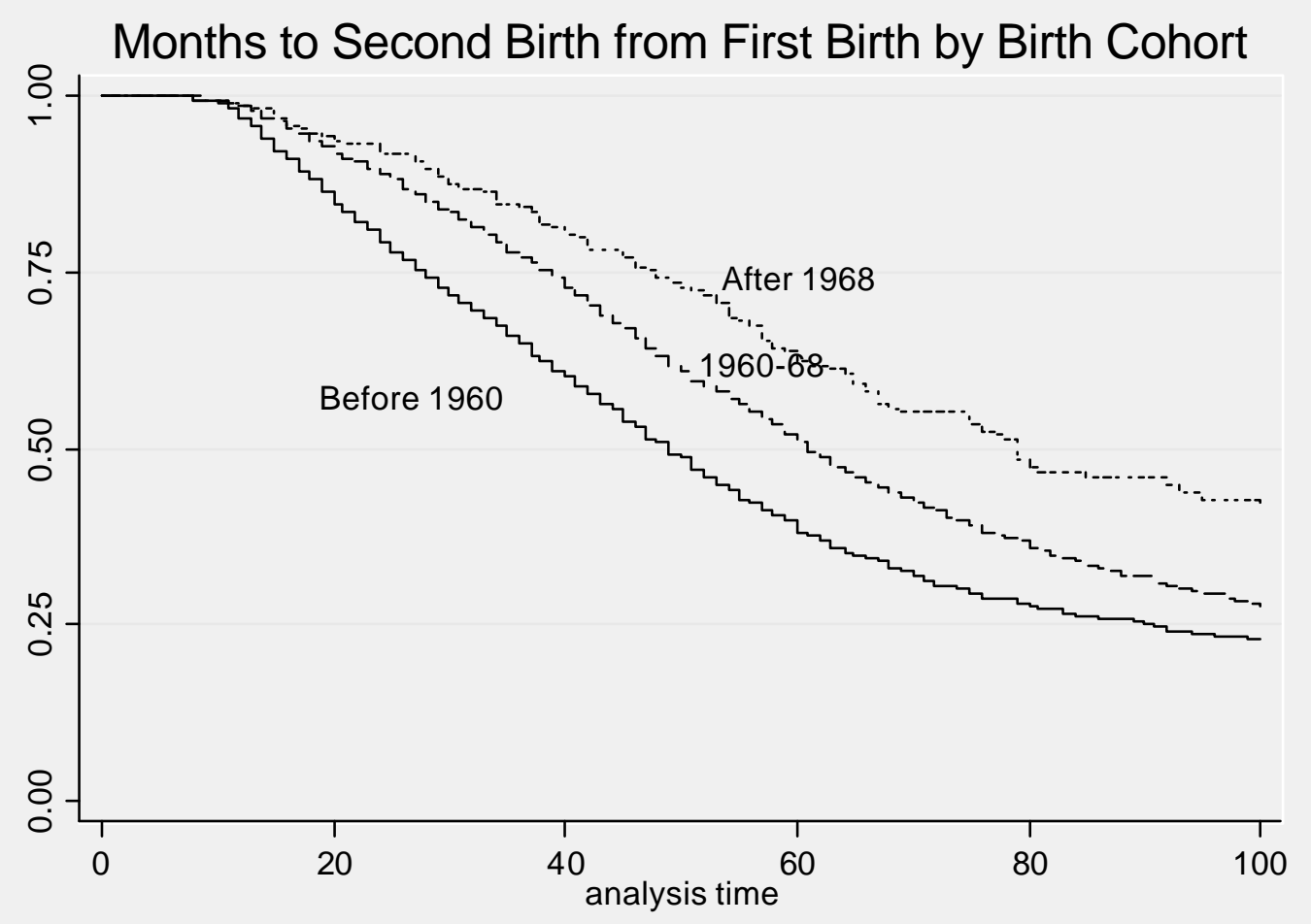

